\title{
Seabed images from Southern Ocean shelf regions off the northern Antarctic Peninsula and in the southeastern Weddell Sea
}

\author{
Dieter Piepenburg ${ }^{1,2}$, Alexander Buschmann ${ }^{1}$, Amelie Driemel ${ }^{1}$, Hannes Grobe ${ }^{1}$, Julian Gutt ${ }^{1}$, \\ Stefanie Schumacher ${ }^{1}$, Alexandra Segelken-Voigt ${ }^{1,3}$, and Rainer Sieger ${ }^{1}$ \\ ${ }^{1}$ Alfred Wegener Institute, Helmholtz Centre for Polar and Marine Research Bremerhaven, \\ Am Handelshafen 12, 26570 Bremerhaven, Germany \\ ${ }^{2}$ Helmholtz Institute for Functional Marine Biodiversity at the University of Oldenburg (HIFMB), \\ Carl-von-Ossietzky-Str. 9-11, 26129 Oldenburg, Germany \\ ${ }^{3}$ Carl von Ossietzky University of Oldenburg, Ammerländer Heerstraße 114-118, 26129 Oldenburg, Germany
}

Correspondence to: Dieter Piepenburg (dieter.piepenburg@awi.de)

Received: 3 March 2017 - Discussion started: 24 March 2017

Revised: 28 May 2017 - Accepted: 14 June 2017 - Published: 21 July 2017

\begin{abstract}
Recent advances in underwater imaging technology allow for the gathering of invaluable scientific information on seafloor ecosystems, such as direct in situ views of seabed habitats and quantitative data on the composition, diversity, abundance, and distribution of epibenthic fauna. The imaging approach has been extensively used within the research project DynAMo (Dynamics of Antarctic Marine Shelf Ecosystems) at the Alfred Wegener Institute, Helmholtz Centre for Polar and Marine Research Bremerhaven (AWI), which aimed to comparatively assess the pace and quality of the dynamics of Southern Ocean benthos. Within this framework, epibenthic spatial distribution patterns have been comparatively investigated in two regions in the Atlantic sector of the Southern Ocean: the shelf areas off the northern tip of the Antarctic Peninsula, representing a region with above-average warming of surface waters and sea-ice reduction, and the shelves of the eastern Weddell Sea as an example of a stable high-Antarctic marine environment that is not (yet) affected by climate change. The AWI Ocean Floor Observation System (OFOS) was used to collect seabed imagery during two cruises of the German research vessel Polarstern, ANT-XXIX/3 (PS81) to the Antarctic Peninsula from January to March 2013 and ANT-XXXI/2 (PS96) to the Weddell Sea from December 2015 to February 2016. Here, we report on the image and data collections gathered during these cruises. During PS81, OFOS was successfully deployed at a total of 31 stations at water depths between 29 and $784 \mathrm{~m}$. At most stations, series of 500 to 530 pictures ( $>15000$ in total, each depicting a seabed area of approximately $3.45 \mathrm{~m}^{2}$ or $2.3 \times 1.5 \mathrm{~m}$ ) were taken along transects approximately $3.7 \mathrm{~km}$ in length. During PS96, OFOS was used at a total of 13 stations at water depths between 200 and $754 \mathrm{~m}$, yielding series of 110 to 293 photos ( 2670 in total) along transects 0.9 to $2.6 \mathrm{~km}$ in length. All seabed images taken during the two cruises, including metadata, are available from the data publisher PANGAEA via the two persistent identifiers at https://doi.org/10.1594/PANGAEA.872719 (for PS81) and https://doi.org/10.1594/PANGAEA.862097 (for PS96).
\end{abstract}




\section{Introduction}

The research project Dynamics of Antarctic Marine Shelf Ecosystems (DynAMo) at the Alfred Wegener Institute, Helmholtz Centre for Polar and Marine Research Bremerhaven (AWI) aimed to comparatively assess the pace and quality of the dynamics in Southern Ocean benthos and endotherms. It is a contribution to the international scientific research program Antarctic Thresholds - Ecosystem Resilience and Adaptation (AnT-ERA) of the Scientific Committee on Antarctic Research (SCAR). By applying a comparative field study approach, the geographical focus of DynAMo was on an area with above-average warming of surface waters and sea-ice reduction around the tip of the Antarctic Peninsula (Gutt, 2013; Gutt et al., 2016) and a stable high-Antarctic marine environment that is not (yet) affected by climate change in the southeastern Weddell Sea (Schröder, 2016).

Special emphasis has been on the study of the spatial distribution patterns of shelf megabenthic epifauna. According to an often-used pragmatic definition proposed by Gage and Tyler (1991), this seabed community fraction is comprised of all organisms that are large enough to be visible in seabed images and/or to be caught by towed sampling gear (i.e., organisms with body sizes larger than approximately $1 \mathrm{~cm})$. They are of ecological significance for Southern Ocean shelf ecosystems (Gutt, 2006), as they affect the small-scale topography of seafloor habitats and hence the structure of the entire benthic community (Gili et al., 2006). In addition, some megabenthic species are sensitive to environmental change due to their slow growth, specific reproduction mode, high degree of environmental adaptation, and narrow physiological tolerances, and can thus serve as early indicators of ecosystem shifts in response to environmental change (Barnes et al., 2009).

Based on several investigations performed during previous cruises of the German research vessel Polarstern to the Antarctic Peninsula and the Weddell Sea, we carried out comparative follow-up field studies in the austral summers of 2013 and 2015-2016. The main objectives were the following:

- to complement surveys of mega-epibenthic assemblages on the shelf off the northern Antarctic Peninsula (cruise PS81 2013) and the southeastern Weddell Sea (cruise PS96 2015-2016), providing further data that are comparable with those obtained in earlier studies in these regions (Biebow et al., 2014);

- to identify the spatial distribution patterns of epibenthic megafauna across multiple spatial scales $(10 \mathrm{~m}, 100 \mathrm{~m}$, $10 \mathrm{~km}$, and $100 \mathrm{~km}$ );

- and to contribute to the standardization of the classification of Antarctic megabenthic communities (Gutt, 2007, 2013).
Seabed images are used for different purposes. These include (1) assessing the large epibenthos as a whole, (2) carrying out quantitative community and diversity analyses, (3) including environmentally relevant (e.g., CTD data if CTD sensors are integrated in OFOS) and visible seabed parameters (e.g., the amount of gravel and debris and the number of ripple marks) at exactly the same spots from which the biological information originates, (4) allowing for analyses with high spatial resolution (patterns within and between adjacent photographs, e.g., to survey the impact of iceberg scouring), and (5) acquiring information on biological interactions, such as epibiotic life mode.

\section{Material and methods}

\subsection{AWI Ocean Floor Observation System}

The AWI Ocean Floor Observation System (OFOS) was used for seabed imaging surveys along drift profiles (transects) to investigate the epibenthic megafauna and its seafloor habitats. The setup and mode of deployment for OFOS was similar to that described by Bergmann and Klages (2012). OFOS is surface-powered gear (Fig. 1) equipped with two downward-looking cameras installed side by side: a highresolution, wide-angle still camera (Canon ${ }^{\circledR}$ EOS 5D Mark III with EF $24 \mathrm{f} / 1.4 \mathrm{~L}$ II lens, f-stop 13, exposure time $1 / 125 \mathrm{~s}$, in-air view angles $74^{\circ}$ horizontal, $53^{\circ}$ vertical, and $84^{\circ}$ diagonal, image size $5760 \times 3840 \mathrm{px}=21 \mathrm{Mpx}$; front of pressure-resistant camera housing consists of plexiglas dome port) and (only in 2015-2016) a high-definition color video camera (Sony ${ }^{\circledR}$ FCB-H11). During cruise PS81, OFOS did not yet include the video camera.

The system was vertically lowered over either the starboard side (PS81) or the stern of the ship (PS96) with a broadband fiber-optic cable until it hovered approximately $1.5 \mathrm{~m}$ above the seabed. It was then towed after the slowly sailing ship at a speed of approximately $0.5 \mathrm{kn}\left(0.25 \mathrm{~m} \mathrm{~s}^{-1}\right)$. The ship's iXBlue POSIDONIA (used during PS81) or the iXBlue global acoustic positioning system (GAPS; used during PS96) in combination with the ultra-short baseline (USBL), inertial navigation system (INS), and satellite-based global positioning system (GPS) technologies provided precise underwater position data for OFOS.

According to the manufacturer specifications, the GPS receiver of the Polarstern (Trimble SPS461) has an accuracy of "better than $5 \mathrm{~m}$ 3DRMS" (without differential signal that was not available during the cruises), and the POSIDONIA and GAPS systems have an accuracy of 0.2 and $0.17 \%$, respectively, of the slant ranges that correlate best with cable lengths, which in turn were very close to water depths at the operational conditions of OFOS deployment during the two cruises (e.g., a low towing speed, so that OFOS was constantly hanging almost directly below the side (PS81) or stern (PS96) of the ship during the entire cast). However, the actual accuracy is known to be generally lower than the manufac- 


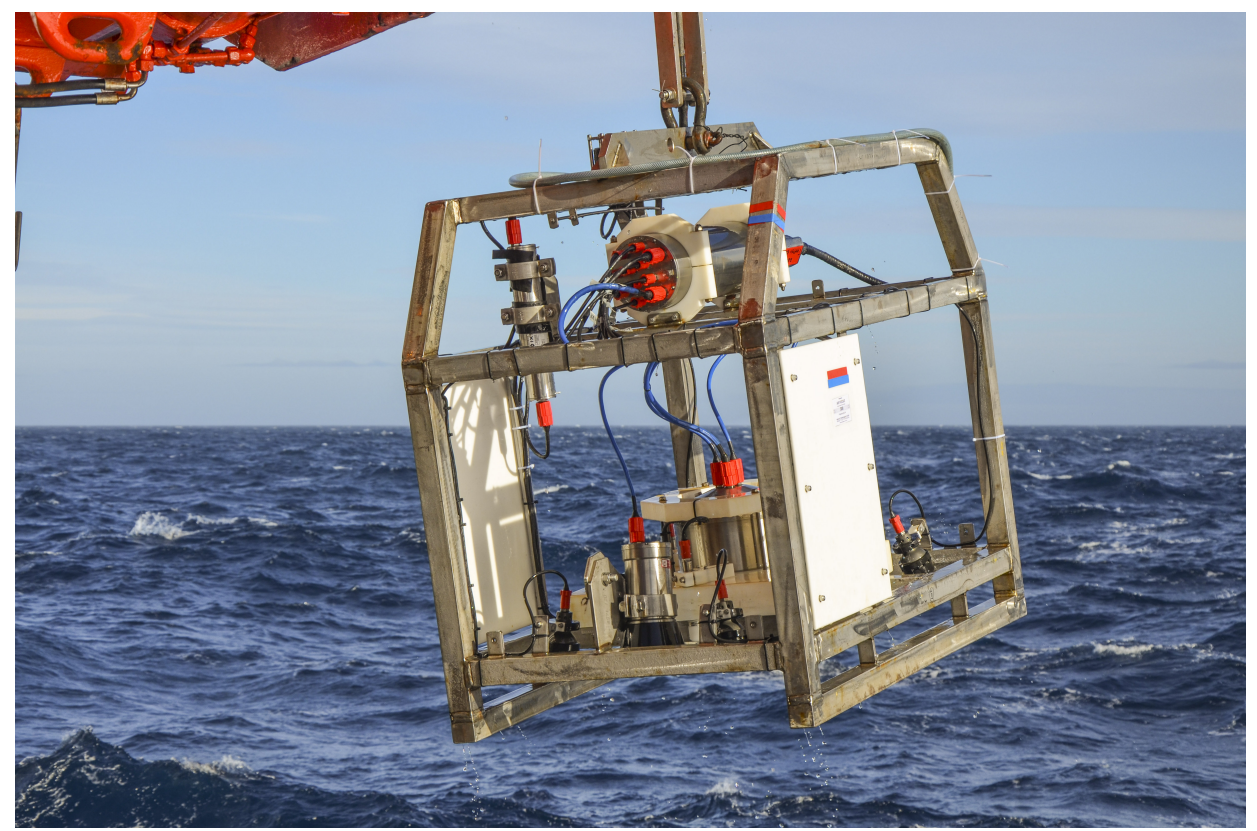

Figure 1. The Ocean Floor Observation System (OFOS) of the Alfred Wegener Institute (AWI), Helmholtz Centre for Polar and Marine Research Bremerhaven, deployed from the RV Polarstern during cruise PS81 in the waters off the northern Antarctic Peninsula from January to March 2013 (photo: A. Segelken-Voigt).

turer specifications because shipboard hydroacoustic systems are highly influenced by a variety of factors (e.g., transducer installation and calibration, ship movements and noise, and acoustic water-column characteristics). Therefore, the actual accuracies of the Polarstern underwater positioning systems were found to be 1 to $1.5 \%$ of the slant range for $95 \%$ of the data based on the ship's data post-processing, filtering, and validation history. This suggests that for the depth range of OFOS stations during PS81 and PS96 (about 30 to $800 \mathrm{~m}$ ), a range of 0.3 to $12 \mathrm{~m}$ should be added to the Polarstern GPS accuracy. The spatial offsets between positioning devices onboard and in the water were corrected automatically. In conclusion, the overall accuracy of the spatial positions for the OFOS-derived seabed images can be estimated to fall into the range of 5 to $15 \mathrm{~m}$, depending on water depths. However, the relative precision in the determination of the spatial intervals between the images taken along a drift transect is assumed to be 1 order of magnitude higher; i.e., these distances can be assessed in terms of precision on an m-scale. Accordingly, the coordinates of the seabed images are given as decimal degrees (DD) expressed to 5 decimal places, corresponding to a spatial resolution in the range of 0.3 (for longitudes at latitudes of about $70^{\circ} \mathrm{S}$ ) to $1.1 \mathrm{~m}$ (for latitudes).

During the profile, OFOS was kept hanging at the preferred height above the seafloor by means of the live video feed and occasional minor cable length adjustments with the winch to compensate for small-scale bathymetric variations in seabed morphology. Information on water depth and height above the seafloor were continuously recorded by means of OFOS-mounted sensors (POSIDONIA transponder in 2013, GAPS transponder in 2015-2016, Tritech altimeter during both PS81 and PS96).

Three lasers, which are placed beside the still camera, emit parallel beams and project red light points arranged as an equilateral triangle with a side length of $50 \mathrm{~cm}$ in each photo. This provides a scale that can be used to calculate the seabed area depicted in each image and/or measure the size of organisms or seabed features visible in the image. In addition, the seabed area depicted was estimated using altimeter-derived height above seafloor and optical characteristics of the OFOS still camera.

In automatic mode, a seabed photo depicting an area of approximately $3.45 \mathrm{~m}^{2}(2.3 \times 1.5 \mathrm{~m}$; with variations depending on the actual height above ground) was taken every $30 \mathrm{~s}$ to obtain series of "timer" stills distributed at regular distances along the profiles that vary in length depending on the duration of the cast. At a ship speed of about $0.5 \mathrm{kn}$, the average distance between seabed images was approximately $5 \mathrm{~m}$. Additional "hotkey" photos were taken of interesting objects (organisms and seabed features, such as putative iceberg scours) when they appeared in the live video feed, which were recorded in addition to the stills for documentation and later analysis.

\subsection{Field sampling}

Within the context of the overall ecological DynAMo working program, OFOS was used to collect seabed imagery during two cruises of the RV Polarstern: the ANT-XXIX/3 


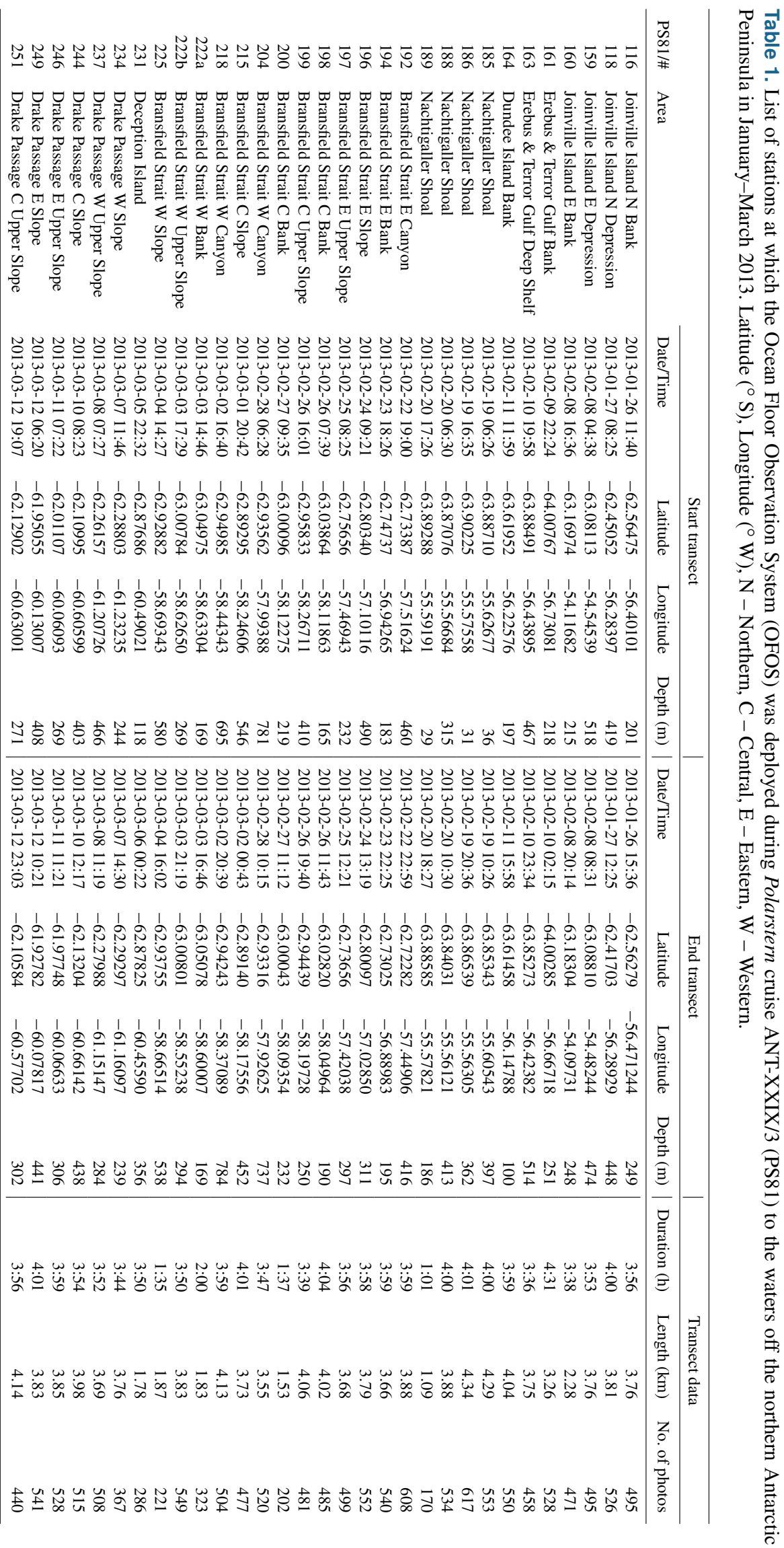




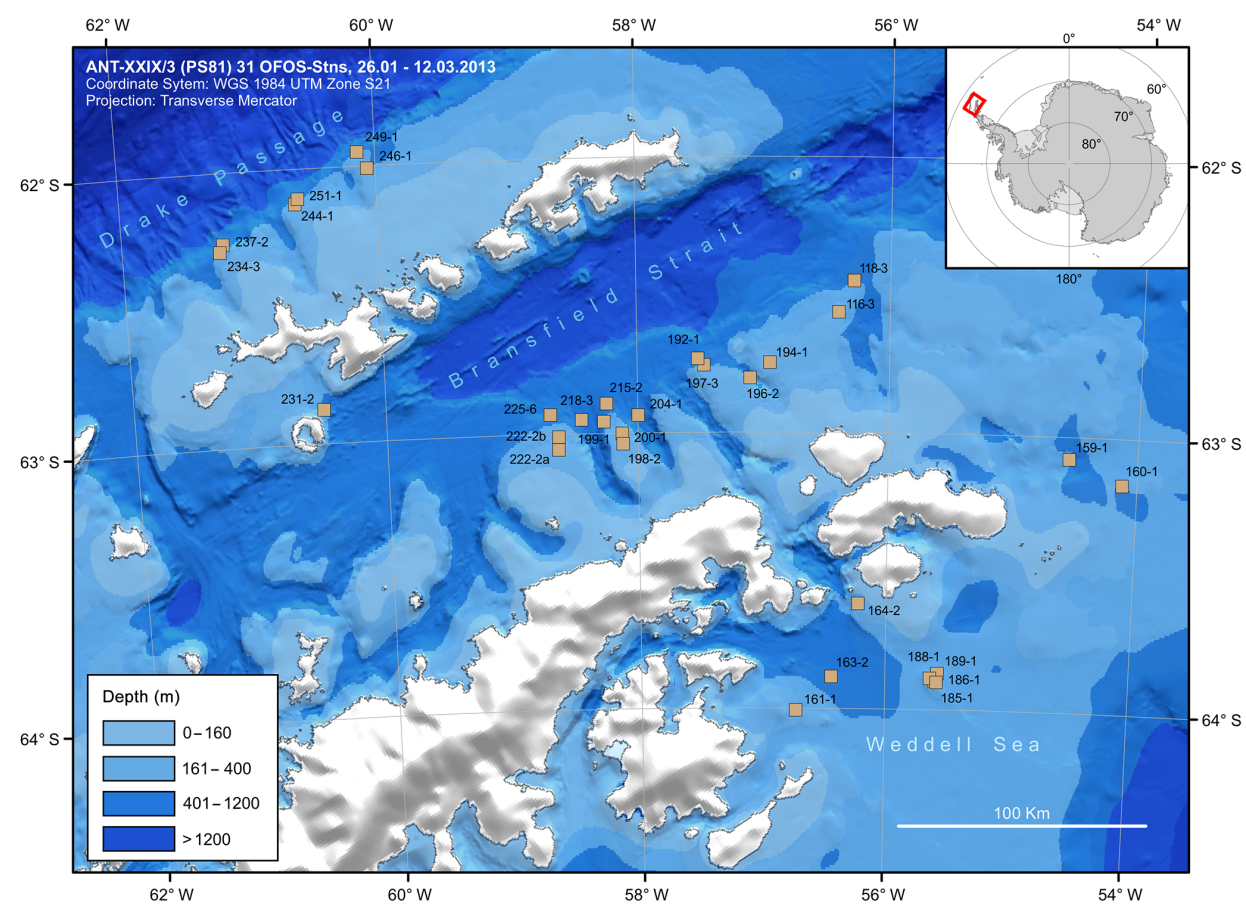

Figure 2. Map of the geographic positions of the stations at which seabed photographs were taken by means of OFOS along photographic transects in three regions (Weddell Sea, Bransfield Strait, and Drake Passage) off the northern Antarctic Peninsula during Polarstern cruise ANT-XXIX/3 (PS81) from January to March 2013.

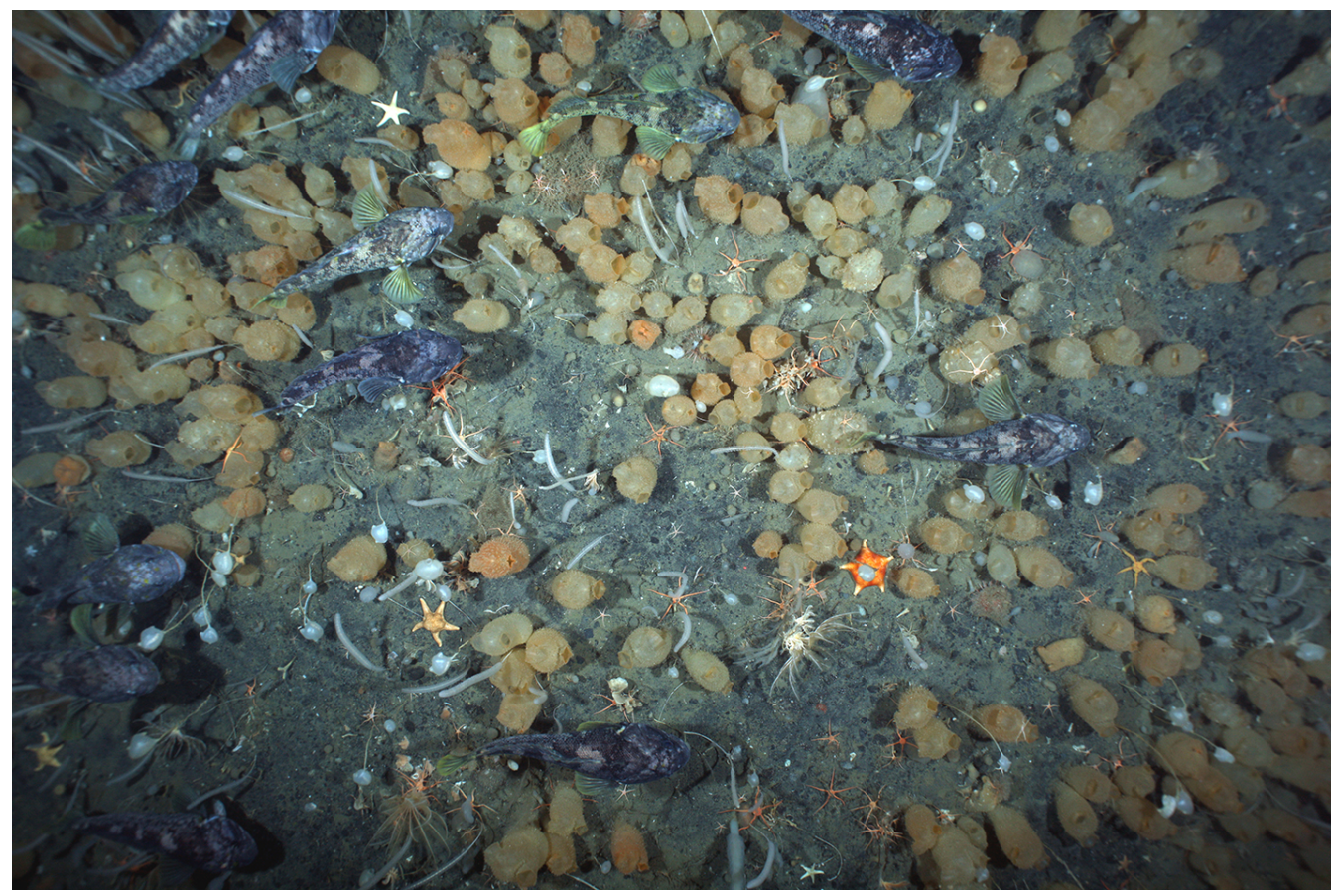

Figure 3. Example of a seabed photo taken during Polarstern cruise ANT-XXIX/3 (PS81) from January to March 2013, showing abundant ascidians and a swarm of demersal nototheniid fish recorded at station PS81/116 on the shelf off Joinville Island in the eastern Bransfield Strait at a water depth of $212 \mathrm{~m}$ on 26 January 2013. 

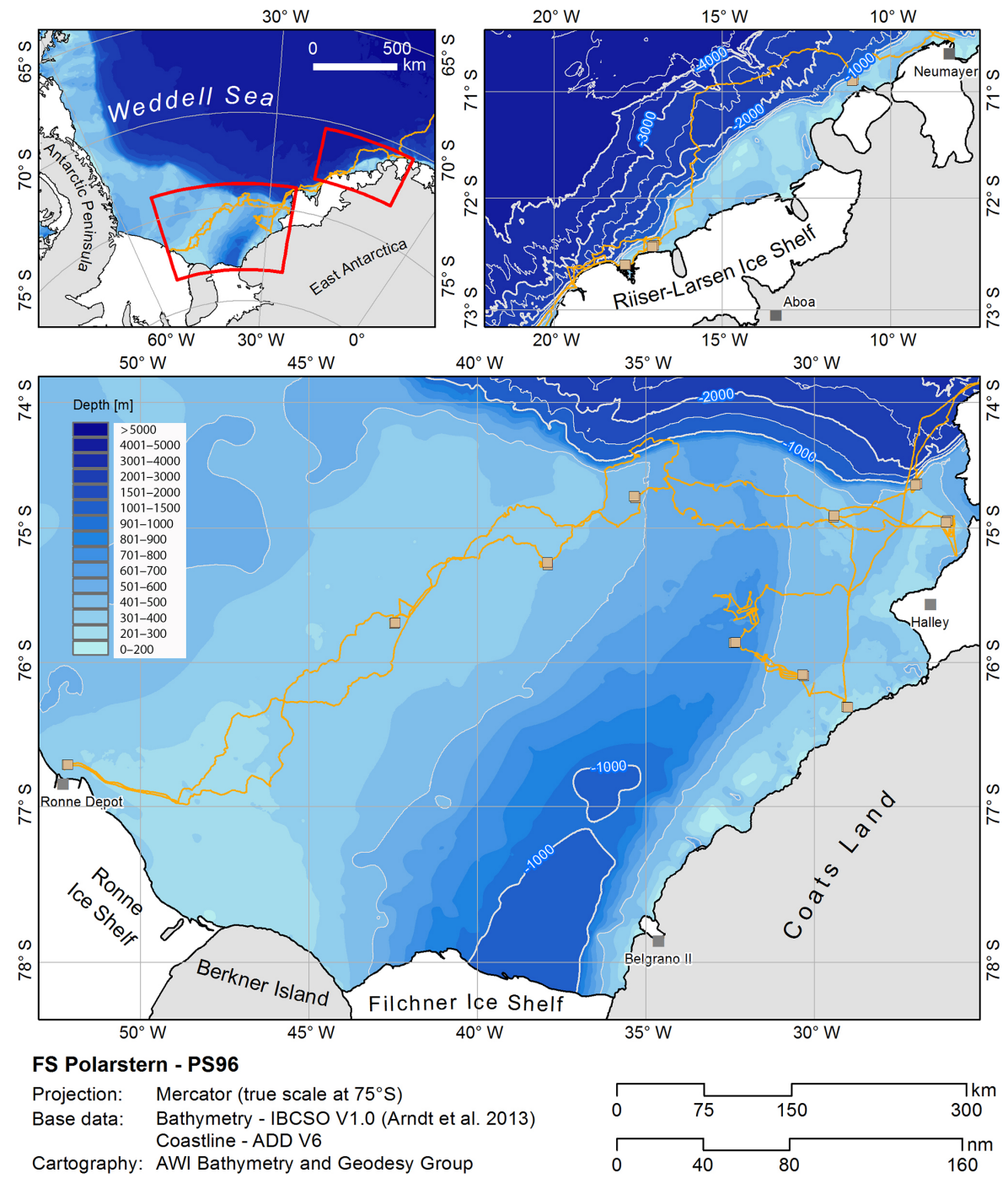

Figure 4. Maps showing the geographic positions of OFOS stations in the Weddell Sea during Polarstern cruise ANT-XXXI/2 (PS96) from December 2015 to February 2016 (after Schröder, 2016). Bathymetric data from IBCSO (Arndt et al., 2013).

(PS81) cruise to the Antarctic Peninsula from January to March 2013 (for cruise report, see Gutt, 2013) and the ANT$\mathrm{XXXI} / 2$ (PS96) cruise to the Weddell Sea from December 2015 to February 2016 (for cruise report, see Schröder, 2016).

\subsubsection{Polarstern cruise ANT-XXIX/3 (PS81)}

During cruise PS81, OFOS was successfully deployed at a total of 31 stations at water depths between 29 and $784 \mathrm{~m}$ (Table 1), delivering a total of more than 15000 seabed photos (Gutt, 2013). At most stations, series of 500 to 530 pictures were taken along transects approximately $3700 \mathrm{~m}$ ( 2 nautical miles) in length during net wire times (with OFOS at the bottom) of $4 \mathrm{~h}$ per transect. At some stations, OFOS had to be deployed for shorter periods of time due to high wave heights and strong winds.
The stations were placed in three regions off the Antarctic Peninsula between 61 and $64^{\circ} \mathrm{S}$ : the northwestern Weddell Sea off Joinville Island, the southern Bransfield Strait, and the southern Drake Passage west of the South Shetland Islands (Fig. 2). These regions are well suited for a comparative ecological study with a biogeographical and ecological background, since they are characterized by different environmental conditions in terms of sea-ice coverage, current regime, and food supply to the benthos. Within these regions, regional habitat blocks were selected that were comprised of bathymetric intermediate-scale shelf-slope gradients (Gutt et al., 2016; Dorschel et al., 2016). In the Bransfield Strait, such bottom topography structures were most obvious, and three distinct habitat blocks were sampled. Within the blocks, single stations were associated with the following defined, primarily depth-related habitats: bank, upper slope, slope, and 


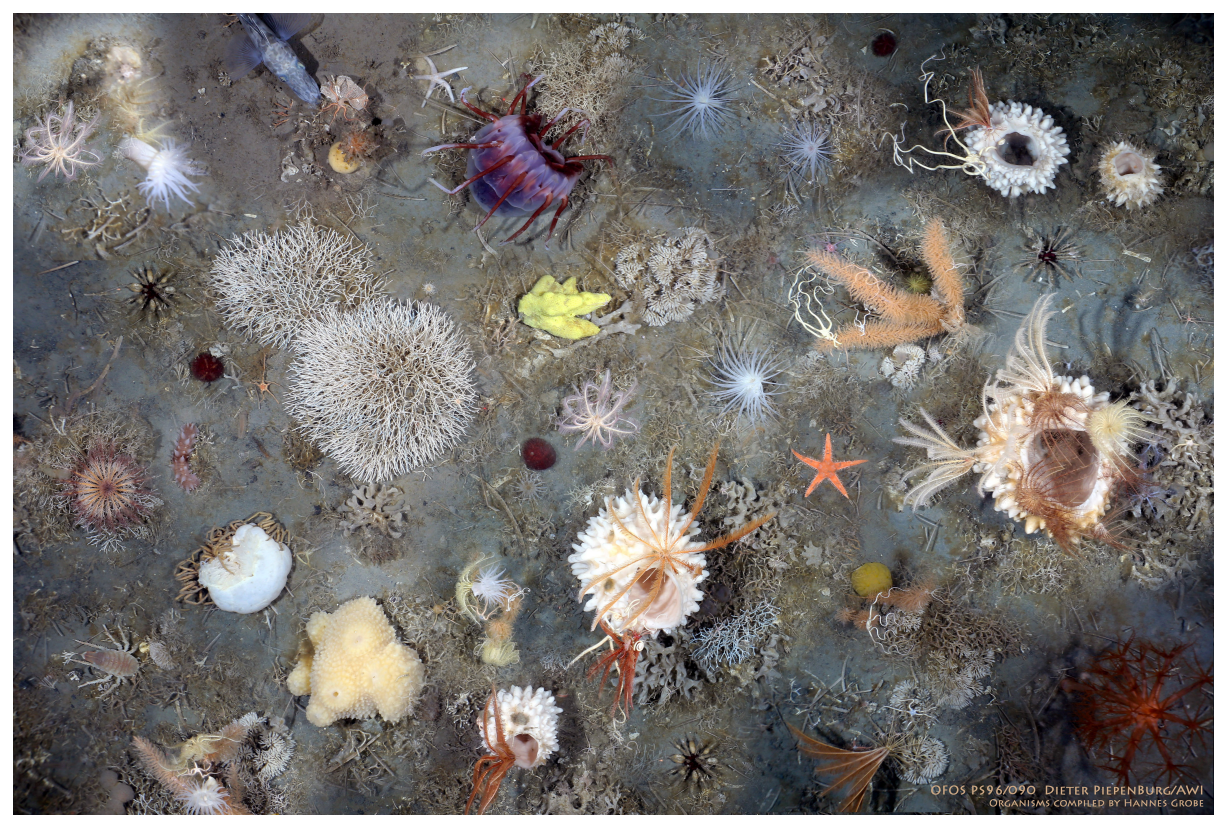

Figure 5. Example of photographic material gathered during Polarstern cruise ANT-XXXI/2 (PS96) to the Weddell Sea from December 2015 to February 2016, showing a compilation of epibenthic megafauna recorded at station PS96/090 on the shelf off the Riiser-Larsen Ice Shelf (Rampen) at water depths from 265 to $310 \mathrm{~m}$ on 29 January 2016 (collage created from 25 clips of seabed images using Adobe Photoshop).

deep or canyon. In the Drake Passage, where the bottom topography was similar albeit less pronounced than in the Bransfield Strait, three habitat blocks were also sampled. In the northern Weddell Sea, stations were selected to cover a range of habitats that are as comparable as possible to those sampled in the Bransfield Strait. Four stations were situated at the northeastern side of the Nachtigaller Shoal on the western Weddell Sea shelf (Dorschel et al., 2014).

Figure 3 is an example of a seabed photo taken at station PS81/110, showing rich megabenthic epifauna (e.g., abundant ascidians and a swarm of demersal nototheniid fish) on the shelf off Joinville Island in the eastern Bransfield Strait at $212 \mathrm{~m}$ of water depth on 26 January 2013.

\subsubsection{Polarstern cruise ANT-XXXI/2 (PS96)}

During cruise PS96, OFOS was deployed at a total of 13 stations at water depths between 200 and $750 \mathrm{~m}$ (Table 2). During the casts with $54 \mathrm{~min}$ to $2 \mathrm{~h} 14 \mathrm{~min}$ of on-ground duration, series of 110 to 293 photos (2670 in total) were obtained along OFOS transects 0.9 to $2.6 \mathrm{~km}$ in length. In addition, a total of more than $14 \mathrm{~h} 50 \mathrm{~min}$ of video footage (available from the first author on request) was recorded.

OFOS stations were distributed over several regions in the southeastern and southern Weddell Sea (Fig. 4). (1) Off Austasen, one transect (PS96/001) was positioned in close vicinity to the BENDEX sites investigated in 2003, 2011, and 2014 (Biebow et al., 2014). Unfortunately, the actual main BENDEX location, artificially disturbed in 2003, could not be revisited, since it was located under fast ice and hence not accessible in December 2015. (2) Four stations (PS96/026, 027, 037, and 048) were located in the main study area of the PS96 cruise, which is the broad shelf of the southern Weddell Sea west of Filchner Trough. (3) Five stations (PS96/007, 008, 010, 057, and 061) were situated on the shelf east of Filchner Trough. Some of these stations were revisits of sites that had been investigated during Polarstern cruise PS82 in 2014 (Knust and Schröder, 2014) using seabed imaging gear other than OFOS: (a) station PS96/008 was close to the position of station PS82/277 $\left(74^{\circ} 54.3^{\prime} \mathrm{S}, 29^{\circ} 40.1^{\prime} \mathrm{W}\right)$, where in 2014 evidence of demersal eggs and nesting and parental care behavior (guarded fish nests) had been recorded; (b) and station PS96/057 was a revisit of an ROV track made in 2014 (from $79^{\circ} 19.1^{\prime} \mathrm{S}$, $29^{\circ} 02.0^{\prime} \mathrm{W}$ to $79^{\circ} 19.3^{\prime} \mathrm{S}, 29^{\circ} 00.9^{\prime} \mathrm{W}$; available on request from Claudio Richter at AWI) close to the coast of Coats Land at water depths of about $240 \mathrm{~m}$, where a rich spongedominated seabed fauna had been recorded. (4) One station (PS96/072) was located in Filchner Trough itself at about $750 \mathrm{~m}$ of depth. (5) Two additional stations (PS96/090 and 106) were situated on the southeastern Weddell Sea shelf close to the mouths of inlets on the edge of the Riiser-Larsen Ice Shelf.

As an example of prominent epibenthic megafauna recorded in seabed photos taken during PS96, see Fig. 5, which shows a compilation of organisms photographed at station PS96/090 on the shelf off the Riiser-Larsen Ice Shelf (Rampen) at water depths from 265 to $310 \mathrm{~m}$ on 29 January 2016. 


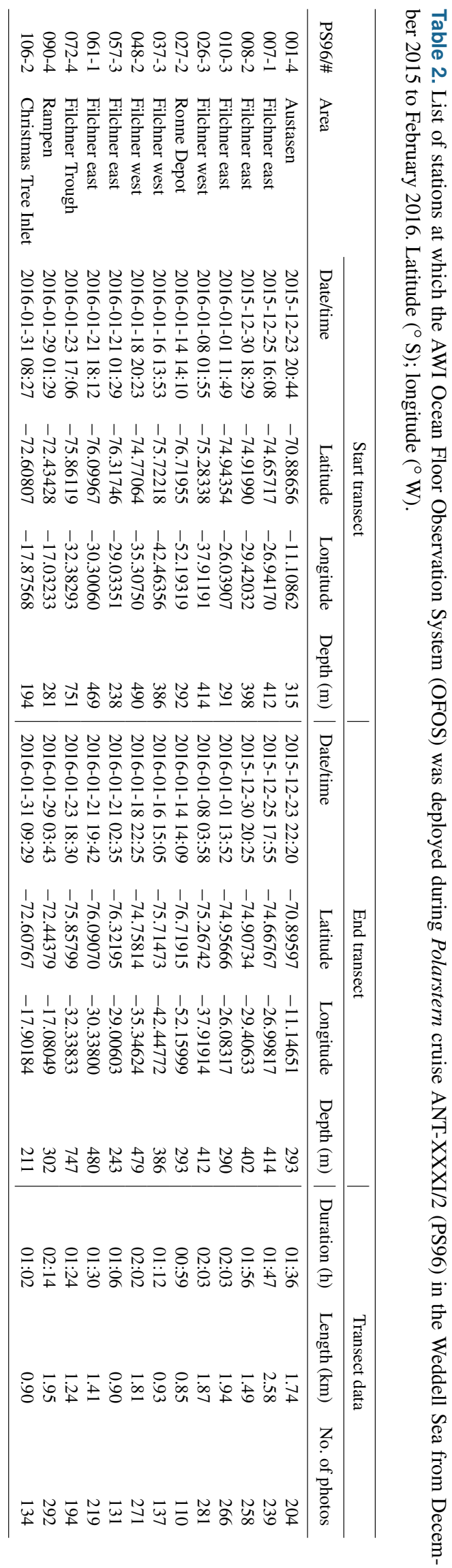

\section{Data availability}

All images taken during the two cruises, including metadata, are available from the data publisher PANGAEA (Piepenburg et al., 2013, for PS81; Piepenburg, 2016, for PS96). Images are listed with a georeference and time for each transect in single-child datasets. All transects for each cruise are grouped in a parent dataset (PS81: https://doi.org/10.1594/PANGAEA.872719; PS96: https://doi.org/10.1594/PANGAEA.862097). This granularity ensures detailed metadata information for each image and each transect. A station map in Google Earth format (kmz) is provided with hot links to the images; see the "Further details" section in the dataset description from PANGAEA. For convenient download of one or multiple image datasets from PANGAEA, special software tools (including instructions on how to install and use them) are available (Sieger, 2012; Buschmann, 2016). Ancillary environmental data for PS81 can be found in Dorschel et al. (2016).

An example for a scientific study based on the analyses of the seabed images, the collection of which are reported here, is an investigation of the composition and distribution patterns of the epibenthic ascidian fauna on the shelves off the Antarctic Peninsula (Segelken-Voigt et al., 2016b). The supplementary information used in this study, including environmental data, is also available from PANGAEA (SegelkenVoigt et al., 2016a). A second example is the investigation of the influence of geomorphological and sedimentological settings on the distribution of epibenthic assemblages on

the Nachtigaller Shoal, a flat-topped submarine hill at the over-deepened shelf of the western Weddell Sea discovered during the PS81 cruise in 2013 (Dorschel et al., 2014).

Competing interests. The authors declare that they have no conflict of interest.

Acknowledgements. We would like to thank the HGF-MPG Joint Research Group for Deep-Sea Ecology and Technology at the Alfred Wegener Institute, Helmholtz Centre for Polar and Marine Research Bremerhaven, for providing access to OFOS during Polarstern cruises PS81 and PS96. The sampling of seabed images during the two cruises was supported by grants AWI_PS81_03 and AWI_PS96_02.

Edited by: Falk Huettmann

Reviewed by: Huw Griffiths and one anonymous referee 


\section{References}

Arndt, J.-E., Schenke, H.W., Jakobsson, M.N., Nitsche, F.-O., Buys, G., Goleby, B., Rebesco, M., Bohoyo, F., Hong, J.K., Black, J, Greku, R., Udintsev, G., Barrios, F., Reynoso-Peralta, W., Taisei, M., and Wigley, R.: The International Bathymetric Chart of the Southern Ocean Version 1.0 - A new bathymetric compilation covering circum-Antarctic waters, Geophys. Res. Lett., 40, 1-7, https://doi.org/10.1002/grl.50413, 2013.

Barnes, D., Griffiths, H., and Kaiser, S.: Geographic range shift responses to climate change by Antarctic benthos: where we should look, Mar. Ecol.-Prog. Ser., 393, 13-26, https://doi.org/10.3354/meps08246, 2009.

Bergmann, M. and Klages, M.: Increase of litter at the Arctic deepsea observatory HAUSGARTEN, Mar. Pollut. Bull., 64, 27342741, https://doi.org/10.1016/j.marpolbul.2012.09.018, 2012.

Biebow, H., Gerdes, D., Isla, E., Knust, R., Pineda, S., and Sands, C.: The BENDEX experiment: follow-up 2. in: The expedition PS82 of the research vessel "Polarstern" to the southern Weddell Sea in 2013/14, edited by: Knust, R. and Schröder, M., Ber. Polarforsch, Meeresforsch., 680, 94-98, https://doi.org/10.2312/BzPM_0680_2014, 2014.

Buschmann, A.: PANGAEA UW-photo download helper for macOS. Alfred Wegener Institute, Helmholtz Centre for Polar and Marine Research, Bremerhaven, https://doi.org/10.1594/PANGAEA.869477, 2016.

Dorschel, B., Gutt, J., Piepenburg, D., Schröder, M., and Arndt, J. E.: The influence of the geomorphological and sedimentological settings on the distribution of epibenthic assemblages on a flat topped hill on the over-deepened shelf of the western Weddell Sea (Southern Ocean), Biogeosciences, 11, 3797-3817, https://doi.org/10.5194/bg-11-3797-2014, 2014.

Dorschel, B., Gut,t J., Huhn, O., Bracher, A., Huntemann, M., Gebhardt, C., Huneke, W., and Schröder, M.: Environmental information for a marine ecosystem research approach for the northern Antarctic Peninsula (RV Polarstern expedition PS81, ANT-XXIX/3), Polar Biol., 39, 765-787, https://doi.org/10.1007/s00300-015-1861-2, 2016.

Gage, J. D. and Tyler, P. A.: Deep-sea biology: a natural history of organisms at the deep-sea floor, Cambridge University Press, Cambridge, 1991.

Gili, J., Arntz, W., Palanques, A., Orejas, C., Clarke, A., Dayton, P., Isla, E., Teixidó, N., Rossi, S., and López-González, P.: A unique assemblage of epibenthic sessile suspension feeders with archaic features in the high-Antarctic, Deep-Sea Res. Pt. II, 53, 1029 105, https://doi.org/10.1016/j.dsr2.2005.10.021, 2006.

Gutt, J.: Coexistence of macro-zoobenthic species on the Antarctic shelf: An attempt to link ecological theory and results, Deep-Sea Res. Pt. II, 53, 1009-1028, https://doi.org/10.1016/j.dsr2.2006.02.012, 2006.
Gutt, J.: Antarctic macro-zoobenthic communities: a review and an ecological classification, Antarct. Sci., 19, 165-182, https://doi.org/10.1017/S0954102007000247, 2007.

Gutt, J. (Ed): The expedition of the research vessel "Polarstern" to the Antarctic in 2013 (ANT-XXIX/3), Ber. Polarforsch. Meeresforsch., 665, 1-150, https://doi.org/10.2312/BzPM_0665_2013, 2013.

Gutt, J., David, B., Isla, E., and Piepenburg D.: High environmental variability and steep biological gradients in the waters off the northern Antarctic Peninsula: Polarstern expedition PS81 (ANT-XXIX/3), Polar Biol., 39, 761-959, https://doi.org/10.1007/s00300-016-1937-7, 2016.

Knust, R. and Schröder, M. (Eds): The expedition PS82 of the research vessel POLARSTERN to the southern Weddell Sea in 2013/2014, Ber. Polarforsch. Meeresforsch., 680, 1-155, https://doi.org/10.2312/BzPM_0680_2014, 2014.

Piepenburg, D.: Seabed photographs taken along OFOS profiles during POLARSTERN cruise PS96 (ANTXXXI/2 FROSN), Alfred Wegener Institute, Helmholtz Center for Polar and Marine Research, Bremerhaven, https://doi.org/10.1594/PANGAEA.862097, 2016.

Piepenburg, D., Segelken-Voigt, A., and Gutt, J.: Seabed photographs taken along OFOS profiles during POLARSTERN cruise PS81 (ANT-XXIX/3), Alfred Wegener Institute, Helmholtz Center for Polar and Marine Research, Bremerhaven, https://doi.org/10.1594/PANGAEA.862719, 2013.

Schröder, M. (Ed): The expedition PS96 of the research vessel "Polarstern" to the southern Weddell Sea in 2015/16, Ber. Polarforsch. Meeresforsch., 700, 1-142, https://doi.org/10.2312/BzPM_0700_2016, 2016.

Segelken-Voigt, A., Bracher, A., Dorschel, B., Gutt, J., Huneke, W., Link, H., and Piepenburg, D.: Spatial distribution patterns of ascidians (Ascidiacea: Tunicata) in combination with information on bathymetry, oceanography, chlorophyll-a, and sea-ice on the continental shelves off the northern Antarctic Peninsula during POLARSTERN cruise ANT-XXIX/3, https://doi.org/10.1594/PANGAEA.849291, 2016a.

Segelken-Voigt, A., Bracher, A., Dorschel, B., Gutt, J., Huneke, W., Link, H., and Piepenburg, D.: Spatial distribution patterns of ascidians (Ascidiacea: Tunicata) on the continental shelves off the northern Antarctic Peninsula, Polar Biol., 39, 863-879, https://doi.org/10.1007/s00300-016-1909-y, 2016 b.

Sieger, R.: PanGet - downloads multiple data sets from PANGAEA. Alfred Wegener Institute, Helmholtz Centre for Polar and Marine Research, Bremerhaven, https://doi.org/10.1594/PANGAEA.804562, 2012. 